\title{
Editorial: Information literacy and the role of national library and information associations
}

\begin{tabular}{|l|l|}
\hline Purpose of this paper & $\begin{array}{l}\text { To investigate the role of national library } \\
\text { associations both in promoting information } \\
\text { literacy and in advancing the interests of the } \\
\text { practitioner library and information worker. }\end{array}$ \\
\hline Design/methodology/approach & $\begin{array}{l}\text { An opinion piece based on information literacy } \\
\text { practice worldwide and recent debate on the role } \\
\text { of national association and professional } \\
\text { organisations in the UK }\end{array}$ \\
\hline Findings & $\begin{array}{l}\text { That the dynamic role of associations for the } \\
\text { library and information profession in a variety of } \\
\text { countries worldwide gives an indication of how } \\
\text { the profession should use its own national } \\
\text { association. }\end{array}$ \\
\hline Practical implications & $\begin{array}{l}\text { This is purely an expression of opinion about the } \\
\text { value of the relationship between national } \\
\text { associations for the library and information } \\
\text { profession and the promotion of information } \\
\text { literacy. }\end{array}$ \\
\hline $\begin{array}{l}\text { Gives some insight into how a national } \\
\text { professional association is uniquely positioned to } \\
\text { support professional status and encourage job } \\
\text { opportunities by forward-looking policy } \\
\text { formulation and cross-sectoral leadership, in } \\
\text { particular in the area of information literacy. }\end{array}$ \\
\hline What is original/value of the & $\begin{array}{l}\text { An attempt to validate at practitioner level the } \\
\text { impact and importance of a national association } \\
\text { by reference to real practice-based examples } \\
\text { and demonstrably successful international } \\
\text { models. }\end{array}$ \\
\hline
\end{tabular}

Keywords: professional associations; libraries; librarians; information literacy.

\section{Introduction}

Librarians often like to debate the role of their national professional association. It is always good to analyse the role of institutions, and bodies such as the American Library Association, the Australian Library and Information Association and the UK's Chartered Institute of Library and Information Professionals (formerly the Library Association) are all certainly well-established institutions. For example, how well do such associations do in terms of promoting employment opportunities for library and information workers and protecting their professional status? A rather energetic bout of such questioning broke out on one of the main email discussion lists run by JISC (the Joint Information Systems Committee, 2004) for librarians in the UK in the Summer of 2004.

This is a peer-reviewed author accepted manuscript of the following research article: Joint, N. and Wallis, J. (2005), "Information literacy and the role of national library and information associations", Library Review, Vol. 54 No. 4, pp. 213-217. https://doi.org/10.1108/00242530510593399 
Anyone interested in the original set of email exchanges can take a look for themselves, though many of the issues raised are quite familiar. An association which runs a vacancies listing service (which inevitably reflects the present less than perfect status and reward of librarianship), has to square this with its essential role in protecting the professional status of its members. If this is difficult enough, how does an association best represent the interests of its members, when their role is shifting as a result of a variety of technological and social changes? After all, there are now other associations and societies who could possibly offer a home to library and information professionals, because their function is probably more fluid than at any previous time in their history.

This editorial article is one in a series of papers in 'Library Review' Volume 54 Number 4 that focus on the international dimensions of information literacy practice today. So it is perhaps appropriate that we use this editorial to look at how professional associations in a number of countries have promoted the issue of information literacy and used it to support the vocational aspirations of their library and information professionals.

Firstly, therefore, we should applaud the achievements of our colleagues in countries such as the USA, Australia and New Zealand who have used their professional association so effectively to promote the importance of information literacy. In a number of ways they have managed to raise the profile of the library and information profession and shown how it is an essential factor in the successful pursuit of information literacy as a vital part of the larger educational system.

For example, in the USA, the Association of College and Research Libraries (ACRL, 2003-04), within the aegis of the American Library Association, has made an invaluable contribution to thinking about information literacy theory and formulation of information literacy practice, and its standards and recommendations have been influential both nationally and internationally. Another important engine driving US dialogue on information literacy is the ILI-L discussion list (Information Literacy Instruction Listserv, originally the Bibliographic Instruction listserv, now hosted by the ALA-ACRL, and closely identified with the Instruction Section of the Association of College and Research Libraries). This is a vital source of information and debate on information literacy.

And one of the many functions of ILI-L, which might interest participants in the Lis-Link debate, is to advertise jobs - with professional status and good salaries - for information literacy librarians. Casting an eye at random over a recent posting to the list, you find an advert for a Full Time Library Faculty Post, Tenure Track, as Business Instruction \& Reference Librarian on a scale rising to the equivalent of 31,000 pounds sterling (which level of remuneration, given the US cost of living and currency fluctuations, is going to satisfy anyone's demands for professional status for librarians). This is evidence of how a national profession supports and promotes its members, from theoretical and reflective policy-making, to advertising and recruiting vacancies.

This is a peer-reviewed author accepted manuscript of the following research article: Joint, N. and Wallis, J. (2005), "Information literacy and the role of national library and information associations", Library Review, Vol. 54 No. 4, pp. 213-217. https://doi.org/10.1108/00242530510593399 
There are of course some who would criticise certain aspects of this US information literacy scene in which professional association activity plays so rich a part. There is arguably a rather bureaucratic and heavily institutionalised feel in all this - looking through the relevant websites, one finds that there are a lot of documents, acronyms and syllabuses, with sections and subsections with carefully detailed numbering. This may give rise to questions about whether the life is being squeezed out of the creative aspects of information literacy education.

However, the simple fact remains that in national educational policymaking, if an educational activity is not institutionalised, it probably doesn't matter very much. In fact, it effectively ceases to exist.

Perhaps this shouldn't be so - perhaps the whole learning process in some national education systems is in danger of becoming over-managed and over-institutionalised. There seems to be a remarkable desire at times for weightily conceptualised learning objectives and lists of essential educational outcomes which can be used as assessment criteria for national standards (though if one engages with the issues informing such statements, the quality of thinking behind them is highly impressive and can only reinforce the profession's intellectual standing). The simple fact is, the system is as it is, and librarians will need to play the system on its own terms if they are to bring their profession's information-related educational priorities to bear upon it.

Thus, it may be a bit dispiriting to see the bureaucratic momentum that has built up behind information literacy work in the USA, but at least it does mean that information literacy is not going to fall off the priority list of any educational bureaucrat in the States. There is nothing that intimidates such bureaucrats more than a weighty set of recommendations and formulations from influential bodies - if they ignore them, then their critics could set about them by unleashing an avalanche of working party reports the collective mass of which would be sufficient to despatch any unsuspecting administrator to an untimely end.

So, in the USA, the national climate of opinion is such that a university vice-principal is more likely to be well-disposed to approve, for example, an application to create a new post for an Information Literacy librarian. The ALA and its various associated sections thus deserve applause on a number of counts:

- The intellectual integrity of their work on information literacy is worthy of high praise.

- Politically, they have raised the profile of an issue of great importance to the profession.

- They have improved the professional status and remuneration levels of library and information workers in consequence.

And without labouring the point, it is possible to see many parallels in other countries. The Australian profession has used the Australian Library

This is a peer-reviewed author accepted manuscript of the following research article: Joint, N. and Wallis, J. (2005), "Information literacy and the role of national library and information associations", Library Review, Vol. 54 No. 4, pp. 213-217. https://doi.org/10.1108/00242530510593399 
and Information Association to actively promote information literacy as part of the core aims of formal education and lifelong learning in Australia, and, more specifically, the ALIA Information Literacy Forum has been at the forefront of this. For example, its AliaINFOLIT email list is a useful discussion forum for the profession. And LIANZA (the Library and Information Association of New Zealand Aotearoa) has put New Zealand in a similar position (Stone, 2000).

The situation in the UK is somewhat different. In the UK, perhaps the most recent significant 'institutionally-sponsored' work in the area of information literacy has come from SCONUL, whose Task Force's work, set out in the position paper 'Information Skills in Higher Education' (SCONUL, 2000) did much to advance the cause of information literacy as a core learning attainment, worthy of embedding in the UK education system at all levels. SCONUL's position in British institutional life is somewhat akin to the ALA-ACRL, but it stands apart from CILIP as an independent entity. The SCONUL Task Force - being allied to Higher Education - was thus positioned differently from the Task Forces of the Australian and New Zealand professional associations. Similarly the main UK email list on this issue, LIS-Infoliteracy, is a good discussion forum, but sits within the JISC family of listservs, yet another distinct institutional environment (and, jobseekers please note, it does not as yet carry the sort of information literacy job that you find on ILI-L). All of these elements work well as part of the national information literacy scene, but they do not quite form a unified picture.

So, it is worth suggesting, at least as a hypothesis, that the British approach to information literacy is typically pragmatic and ad hoc, with a less integrated, overarching institutional structure than we see in other countries. There is a certain practicality in all this - it is in some ways better to get on with something locally and 'just do it' than worry too much about big theories and organisational structures. This is a very British state of affairs, with many parallels elsewhere in national life (for example, the UK is the country of case law - we reject Napoleonic codes and a priori constitutional statements.) If things that work well in the given situation sometimes evolve into a bigger consensus, that is fine, but, in this pragmatic worldview, it has to be something that evolves of its own accord. And if it doesn't, well, the heterogeneous status quo is acceptable. The UK information literacy scene is therefore rich, in some ways uniquely so, with conferences such as the eLit series (eLit, 2005) providing a forum for exchange of ideas on information literacy in the original and stimulating context of other concepts such as IT literacy and e-learning under the umbrella concept of 'eliteracy'. Indeed this collection of papers tries to echo that interest in eliteracy by looking at information literacy amongst information users and IT literacy amongst information professionals.

However, national organisational structures do create an enabling environment in which more gets done, and they also create a framework for theories and policies that help the profession progress its aims. The

This is a peer-reviewed author accepted manuscript of the following research article: Joint, N. and Wallis, J. (2005), "Information literacy and the role of national library and information associations", Library Review, Vol. 54 No. 4, pp. 213-217. https://doi.org/10.1108/00242530510593399 
lesson from other countries may well be that the national professional association is a uniquely powerful agent that can create synergies between all the separate elements involved in the national information literacy project. Thus, we in the UK may need the results that a national association is well placed to achieve, but do we work through the national association to achieve our goals?

Fortunately, the situation is increasingly positive in the UK, so the answer is 'Yes, we are working in that way'. A number of intelligent, dynamic and forward-looking library professionals have created the new Information Literacy group within CILIP, a development of enormous promise that above all shows how a national professional association is ideally positioned to integrate activity on an issue across all sectors of the profession and all sectors of the national education scene.

The recently created Information Literacy group works under the aegis of the Community Services Group (CSG) within CILIP and has its first national conference in 2005 (LILAC, 2005), in association with ASSIGN. Both through the wide cross-sectoral range of its conference themes (ranging from HE through school libraries to the broadest issue of widening participation) and through its relationship with the CSG, the Information Literacy group shows how CILIP is invaluably placed to promote new possibilities for integration and organic development in the UK national information literacy project. SCONUL, for all its merits as a tertiary education and national library body, cannot quite promote information literacy as (say) a schools library issue, or a whole community issue in the same way as the national association can. The UK professional association can give this wider view and facilitate a range of collaboration and cross-sectoral initiatives.

So information literacy is moving from strength to strength in the UK and we should welcome the impetus given to it by the Information Literacy group of CILIP. But this progress would not be possible without the energy and intelligence of the library professionals who have committed to it in this way. For all of us who want more from a professional association, there is a clear way forward here, one which deserves not only applause, but above all emulation and participation.

Nicholas Joint, University of Strathclyde, Scotland, Editor, 'Library Review, Jake Wallis, Centre for Digital Library Research, Reviews Editor, 'Library Review'.

This is a peer-reviewed author accepted manuscript of the following research article: Joint, N. and Wallis, J. (2005), "Information literacy and the role of national library and information associations", Library Review, Vol. 54 No. 4, pp. 213-217. https://doi.org/10.1108/00242530510593399 


\section{References}

ACRL, Association of College and Research Libraries. Information literacy resources from the Association of College \& Research Libraries, 2003-04. < http://www.ala.org/ala/acrl/acrlissues/acrlinfolit/informationliteracy.htm > (accessed January 21st 2005)

ALIA Information Literacy Forum < http://alia.org.au/groups/infolit/ > (accessed January $25^{\text {th }} 2005$ )

ASSIGN, Social Science Information Group and Network < http://www.Ise.ac.uk/library/other_sites/aliss/> (accessed January 21st 2005)

eLit 2005 - eLit conference series < http://www.elit-conf.org/ > (accessed January 21st 2005)

Information Literacy Group, CILIP. $<$ http://www.cilip.org.uk/groups/csg/csg ilg/index.html > (last accessed January $25^{\text {th }} 2005$ ).

The Joint Information Systems Committee, 2004: JISCmail - Mailing Lists. LIS-LINK Archives - August 2004. Threads: 'Value of CILIP?' and 'Value of CILIP to academic librarians'

< http://www.jiscmail.ac.uk/lists/LIS-LINK.html > (accessed January 21st 2005)

LILAC, Librarians' Information Literacy Annual Conference, 2005. $<$ http://Ittg.Ise.ac.uk/LILAC/ > (accessed January 21st 2005)

SCONUL (1999) Information skills in higher education: a SCONUL Position Paper. < http://www.sconul.ac.uk/pubs_stats/pubs/99104Rev1.doc > (accessed January 25th 2005)

Stone, L./LIANZA Taskforce on Information Literacy (2000). User Education And Information Literacy In New Zealand: A Country Paper. < http://www.lianza.org.nz/text_files/information_literacy.doc> (accessed January 21st 2005)

This is a peer-reviewed author accepted manuscript of the following research article: Joint, N. and Wallis, J. (2005), "Information literacy and the role of national library and information associations", Library Review, Vol. 54 No. 4, pp. 213-217. https://doi.org/10.1108/00242530510593399 